\begin{tabular}{|c|c|c|}
\hline & Int.J.Curr.Microbiol.App.Sci (2021) 10(12): 7-13 & \\
\hline & $\begin{array}{l}\text { International Journal of Current Microbiology and Applied Sciences } \\
\text { ISSN: 2319-7706 Volume } \mathbf{1 0} \text { Number } \mathbf{1 2} \mathbf{( 2 0 2 1 )} \\
\text { Journal homepage: } \underline{\text { http://www.ijcmas.com }}\end{array}$ & 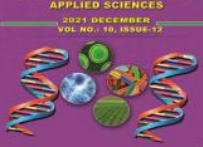 \\
\hline $\begin{array}{l}\text { EXCELLENT } \\
\text { PUBLISHERS }\end{array}$ & & \\
\hline
\end{tabular}

\title{
Soil Carbon Fractions, Growth and Yield as Affected by Different Nutrient Management in Fodder Maize (Zea mays L.)
}

\author{
Geethu Jacob*, K. C. Manorama Thampatti and Naveen Leno \\ Department of Soil Science and Agricultural Chemistry, College of Agriculture, \\ Vellayani, Kerala Agricultural University, Kerala, India \\ *Corresponding author
}

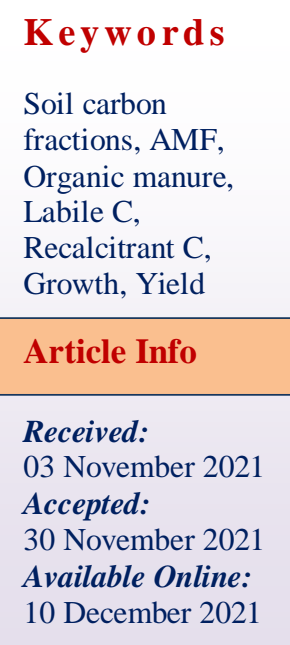

\section{Keywords}

Soil carbon

fractions, AMF,

Organic manure,

Labile C

Recalcitrant C,

Growth, Yield

Article Info

Received:

Accepted:

30 November 202

10 December 2021

\section{A B S T R A C T}

The present study investigated the effect of different nutrient management practices on soil $\mathrm{C}$ fractions, growth and yield of fodder maize variety- African tall. The treatments were seven in number $-\mathrm{T}_{1}$ : POP recommendation, $\mathrm{T}_{2}$ : Soil test based POP, $\mathrm{T}_{3}$ : Organic nutrient management using TOF-F, $\mathrm{T}_{4}$ : POP + AMF, $\mathrm{T}_{5}$ : Soil test based POP + AMF, $\mathrm{T}_{6}$ : Organic nutrient management $+\mathrm{AMF}$, and $\mathrm{T}_{7}$ : Absolute control. Among the soil $\mathrm{C}$ fractions, highest TOC content was recorded by $\mathrm{T}_{3}$ which was on par with $\mathrm{T}_{5}$ and $\mathrm{T}_{6}$ and highest DOC content was observed for $\mathrm{T}_{1}$ at both levels of sampling depths. The soil labile and recalcitrant fractions followed same trend at both levels of depth of sampling i.e. $\mathrm{T}_{5}$ was found to be superior which was on par with $\mathrm{T}_{6}$. The highest value for shoot weight, root volume, green fodder and dry fodder yield was observed in treatment $T_{5}$ which was on par with $T_{4}$. The root weight was higher for organic nutrient and AMF combination treatment $-\mathrm{T}_{6}(50.23 \mathrm{~g} / \mathrm{plant})$. The results indicated an increased AMF activity in soil test based and organic manured treatments and inoculation with AMF resulted in better growth and yield of fodder maize in all the treatments. The correlation study indicated a strong positive correlation between labile and recalcitrant soil $\mathrm{C}$ fractions and fodder yield of maize giving an insight to the importance those $\mathrm{C}$ fractions in microbial growth, nutrient cycling, and plant growth.

\section{Introduction}

Soil organic carbon (SOC) is one of the most widely used soil quality indicators which affects various soil chemical, physical and biological properties and plays a primary role in multiple soil functions in agricultural soils, such as nutrient cycling, soil aggregate formation, water retention and habitat provision for biodiversity (Else et al., 2019). Soil organic carbon also plays an important role in climate regulation, with the potential of increasing carbon sequestration, offsetting fossil-fuel emissions and counteracting yield reduction created by extreme weather events (Lal, 2004). Among the soil $\mathrm{C}$ fractions, labile carbon which exhibit characteristics of fast decomposition has potential as an indicator of 
soil functions, in particular: nutrient cycling, soil aggregate formation, carbon sequestration and habitat provision for biodiversity (Else et al., 2019). On the other hand, recalcitrant carbon pools (RCP) take more time to decompose and are not readily available to microorganisms (Lal, 2004). The RCP can be represented by humic substances (humin-HU, humic acid-HA, and fulvic acidFA).Therefore, both pools recalcitrant and labile can elucidate how the soil has been used and which management is adequate to increase carbon stocks, mainly in tropical conditions (Stevenson, 1994). Agricultural measures that are aimed at increasing SOC stocks are therefore becoming a priority worldwide. AMF are soil borne fungi that have the capability to improve plant nutrition by increasing the availability as well as translocation of various nutrients especially phosphates and increases the resistance to several abiotic stress factors (Rouphael et al., 2015; Sun et al., 2018; Begum et al., 2019). Formation of hyphal network by the AMF with plant roots significantly enhances the access of roots to a large soil surface area, causing improvement in plant growth (Bowles et al., 2016) and also improves the soil quality by influencing its structure and texture (Thirkell et al., 2017).

Besides that fungal hyphae can expedite the decomposition process of soil organic matter as priming effects mediated by AM hyphal exudation can support microbial communities mineralizing SOM and thereby extend plantmediated impacts on $\mathrm{C}$ and $\mathrm{N}$ cycling beyond the rhizosphere (Paterson et al., 2016).

Despite the importance of SOC, its depletion is one of the main threats for agricultural soils. The fortification of organic manures, retention of crop residues, reduced tillage practices, use of bio fertilizers, integrated nutrient management techniques and improved varieties of field crops, soil test based fertilizer applications etc are some of the attempts to enhance organic $\mathrm{C}$ levels in soil and to attain agricultural sustainability and profitability. Numerous studies have examined the longterm effects of residue management and fertilization on SOC and labile organic C fractions. Little attention has been paid to the short-term effects of different nutrient management practices on $\mathrm{C}$ fractions in soil.

The present study was conducted to evaluate the effect of nutrient management on soil $\mathrm{C}$ fractions, growth and yield parameters of fodder maize.

\section{Materials and Methods}

The experiment was conducted during JuneAugust, 2020 using fodder maize variety African Tall as the crop under conventional tillage and irrigated conditions at the College of Agriculture, Vellayani, KAU. The treatment details were listed below.

$\mathrm{T}_{1}$ : Package of practices (POP)

Recommendation

$\mathrm{T}_{2}$ : Soil test based POP

$\mathrm{T}_{3}$ : Organic nutrient management (using thermochemical fortified organic fertilizer (TOF-F)

$\mathrm{T}_{4}: \mathrm{POP}+\mathrm{AMF}$ (Arbuscular mychorrhizal Fungi)

$\mathrm{T}_{5}$ : Soil test based POP $+\mathrm{AMF}$

$\mathrm{T}_{6}$ : Organic nutrient management $+\mathrm{AMF}$

$\mathrm{T}_{7}$ : Absolute control

The thermochemical organic fertilizer was prepared as per patented KAU - Suchitha technology (Sudharmaidevi et al., 2017). Fresh waste was ground to uniform 
consistency in the grinder unit of the KAU Suchitha waste processing machine and was boiled at $100{ }^{0} \mathrm{C}$ in the reactor unit after adding the chemical reagents like $\mathrm{HCl}(0.25$ $\mathrm{N}, 50 \mathrm{ml} \mathrm{kg}{ }^{-1}$ waste) for $30 \mathrm{~min}$ followed by $\mathrm{KOH}\left(0.5 \mathrm{~N}, 100 \mathrm{ml} \mathrm{kg}^{-1}\right.$ waste) for $30 \mathrm{~min}$. Processing was completed within one hour and TOF was produced. Coir pith @ $40 \mathrm{~g} \mathrm{~kg}^{-1}$ waste and charcoal powder @ $30 \mathrm{~g} \mathrm{~kg}^{-1}$ was added and sun dried to reduce the moisture content.

The TOF-F was prepared for the study by fortifying the TOF with $\mathrm{N}(1.5 \%)$ as groundnut cake, $\mathrm{P}(1 \%)$ as rock phosphate, $\mathrm{Ca}$ (1\%) as calcium carbonate, $\mathrm{Mg}(0.5 \%)$ as magnesium sulphate, $\mathrm{Zn}$ (50 ppm) as zinc sulphate, and B (5 ppm) as borax.

The POP recommendation (KAU, 2016) was followed and organic manures were applied in terms of nitrogen equivalence for treatments $\mathrm{T}_{3}$ and $\mathrm{T}_{6}$. The AMF was applied @5 g per plant. The treatments $T_{2}$ and $T_{5}$ were fixed as per POP soil test based recommendations for field crops.

The soil samples were collected from two depths $-0-20 \mathrm{~cm}$ and $20-60 \mathrm{~cm}$ and were analyzed for different $\mathrm{C}$ fractions as per standard methods.

The total organic C (TOC) content by weight loss on ignition (FAI, 2017), dissolved organic C (DOC) - titrimetry (Jones and Willet, 2006), labile carbon (LC) $-\mathrm{KmnO}_{4}$ oxidation (Blair et al., 1995) and recalcitrant carbon (RC) modified Walkley and Black titration (Chan et al., 2011), The growth and yield parameters were also recorded from the observational plants at milky cob stage of fodder maize.

Statistical analysis were done for all parameters by standard procedures using ANOVA table developed using statistical software - GRAPES (Gopinath, 2021)

\section{Results and Discussion}

\section{Effect of nutrient management practices on soil $\mathbf{C}$ fractions}

The highest soil TOC content was recorded in treatment $T_{3}$ which was on par with $T_{5}$ and $T_{6}$ at both depths of sampling. The treatment $\mathrm{T}_{1}$ had highest DOC value at the two depths of sampling followed by $\mathrm{T}_{4}$ and lowest value was for treatment $\mathrm{T}_{7}$. Regarding the $\mathrm{LC}$, the highest value was observed for $\mathrm{T}_{5}$ which was on par with $\mathrm{T}_{6}$ followed by $\mathrm{T}_{4}$ and lowest value was for control at both levels of sampling depths. The RC content in soil followed the same trend of LC at both levels of sampling depths.

As it is evidenced from Table 1, all the $\mathrm{C}$ fractions had lower values at $20-60 \mathrm{~cm}$ than at $0-20 \mathrm{~cm}$ depth. The SOC fraction is directly derived from recent plant inputs, whether surface deposition of aboveground litter or root turnover, which decreases exponentially with depth, and has a relatively short mean residence time (Sanderman et al., 2021). For most soils, where vertical transport is on the order of a $0.5-2.0 \mathrm{~mm}$ year $^{-1}$ (Kaste et al., 2007), this means that most SOC is mineralized or transformed into more stable forms by microbial cycling before moving deeper in the soil profile. The treatment of organic nutrient management $-\mathrm{T}_{3}$ and $\mathrm{T}_{6}$ were found to be superior in soil TOC content than other nutrient management practices revealing the effect of organic manures in enhancing the soil organic carbon levels as universally accepted and reported (Voltr et al., 2021). AMF can explore and multiply more in organically manured and soil test based fertilizer application treatments. The treatments with AMF combination had higher soil LC and RC content and among them organic nutrient management and soil test based fertilizer application were found to be superior. This result would be consistent with 
the interaction of these hyphae and their associated microbiota being particularly efficient in priming of SOM mineralization.

This could occur through greater effects of hyphal exudates on components of the microbiota active in SOM mineralization, greater hyphal access to potentially mineralisable SOM or a combination of both mechanisms (Paterson et al., 2016).

\section{Effect of nutrient management practices on growth and yield}

The treatment $T_{4}$ had highest value for plant height followed by $\mathrm{T}_{5}$ which was on par with $T_{6}$. The shoot weight, green fodder yield and dry fodder yield showed a similar trend where $\mathrm{T}_{5}$ recorded highest value which was on par with $T_{4}$ followed by $T_{6}$. Regarding the root weight $\mathrm{T}_{6}$ had highest value followed by $T_{5}$. The treatment $T_{5}$ had higher root volume also. The treatment $T_{5}$ which was the combination of soil test based POP and AMF produced highest shoot biomass which resulted in its higher green fodder as well as dry fodder yield. The above result hinted to the fact that inoculation of AMF can enhance the concentration of various macro-nutrients and micro-nutrients significantly, which leads to an increased photosynthate production and hence resulted in increased biomass accumulation (Chen et al., 2017; Mitra et al., 2019).

Table.1 Effect of different nutrient management on soil C fractions at two depths of sampling

\begin{tabular}{|c|c|c|c|c|c|c|c|c|}
\hline \multirow[b]{2}{*}{ Treatments } & \multicolumn{4}{|c|}{$0-20 \mathrm{~cm}$} & \multicolumn{4}{|c|}{$20-60 \mathrm{~cm}$} \\
\hline & $\begin{array}{c}\text { TOC } \\
\%\end{array}$ & $\begin{array}{c}\text { DOC } \\
\text { mg kg-1 }^{-1}\end{array}$ & $\begin{array}{c}\mathrm{LC} \\
\mathrm{mg} \mathrm{kg}^{-1}\end{array}$ & $\begin{array}{c}\text { RC } \\
\%\end{array}$ & $\begin{array}{c}\text { TOC } \\
\%\end{array}$ & $\begin{array}{c}\text { DOC } \\
\mathrm{mg} \mathrm{kg}^{-1}\end{array}$ & $\begin{array}{c}\mathrm{LC} \\
\mathrm{mg} \mathrm{kg}^{-1}\end{array}$ & $\begin{array}{c}\text { RC } \\
\%\end{array}$ \\
\hline $\mathrm{T}_{1}$ & $3.06^{b c}$ & $33.44^{\mathrm{a}}$ & $720.26^{d}$ & $0.94^{\mathrm{d}}$ & $2.90^{b c}$ & $29.48^{a}$ & $547.68^{d}$ & $0.70^{\mathrm{d}}$ \\
\hline $\mathrm{T}_{2}$ & $3.03^{c}$ & $30.49^{c}$ & $765.75^{c}$ & $1.18^{\mathrm{c}}$ & $2.87^{\mathrm{c}}$ & $26.61^{c}$ & $598.26^{c}$ & $0.95^{\mathrm{c}}$ \\
\hline $\mathrm{T}_{3}$ & $3.20^{\mathrm{a}}$ & $27.14^{\mathrm{e}}$ & $783.14^{\mathrm{c}}$ & $1.48^{\mathrm{b}}$ & $3.04^{\mathrm{a}}$ & $23.30^{\mathrm{d}}$ & $618.92^{b c}$ & $1.12^{\mathrm{b}}$ \\
\hline $\mathrm{T}_{4}$ & $3.03^{\mathrm{c}}$ & $31.81^{\mathrm{b}}$ & $830.72^{b}$ & $1.42^{b}$ & $2.89^{b c}$ & $28.40^{\mathrm{b}}$ & $644.99^{b}$ & $1.19^{b}$ \\
\hline $\mathrm{T}_{5}$ & $3.12^{\mathrm{abc}}$ & $28.79^{d}$ & $897.00^{\mathrm{a}}$ & $1.74^{\mathrm{a}}$ & $2.99^{\mathrm{ab}}$ & $27.22^{c}$ & $708.30^{\mathrm{a}}$ & $1.26^{\mathrm{a}}$ \\
\hline $\mathrm{T}_{6}$ & $3.15^{\mathrm{ab}}$ & $25.04^{f}$ & $879.81^{\mathrm{a}}$ & $1.77^{\mathrm{a}}$ & $3.02^{\mathrm{a}}$ & $23.45^{\mathrm{d}}$ & $697.64^{a}$ & $1.30^{\mathrm{a}}$ \\
\hline $\mathrm{T}_{7}$ & $3.02^{c}$ & $33.06^{\mathrm{a}}$ & $645.12^{\mathrm{e}}$ & $0.86^{\mathrm{d}}$ & $2.89^{\mathrm{bc}}$ & $21.13^{\mathrm{e}}$ & $452.88^{\mathrm{e}}$ & $0.63^{\mathrm{e}}$ \\
\hline $\operatorname{SEm}( \pm)$ & 0.035 & 0.282 & 11.146 & 0.027 & 0.035 & 0.296 & 9.218 & 0.02 \\
\hline $\mathrm{CD}(0.05)$ & 0.109 & 0.868 & 34.346 & 0.082 & 0.106 & 0.912 & 28.403 & 0.062 \\
\hline
\end{tabular}

Table.2 Effect of different nutrient management on growth and yield of fodder maize

\begin{tabular}{|c|c|c|c|c|c|c|}
\hline Treatments & $\begin{array}{c}\text { Plant } \\
\text { height } \\
(\mathbf{m})\end{array}$ & $\begin{array}{c}\text { Shoot weight } \\
(\mathbf{g})\end{array}$ & $\begin{array}{c}\text { Root } \\
\text { weight } \\
(\mathbf{g})\end{array}$ & $\begin{array}{c}\text { Root } \\
\text { volume } \\
\left(\mathbf{g} / \mathbf{c m}^{\mathbf{3}}\right.\end{array}$ & $\begin{array}{c}\text { Green fodder } \\
\text { yield (tonnes } \\
\text { /ha) }\end{array}$ & $\begin{array}{c}\text { Dry fodder } \\
\text { yield } \\
(\mathbf{t o n n e s} / \mathbf{h a})\end{array}$ \\
\hline $\mathrm{T}_{1}$ & $2.14^{\text {cd }}$ & $181.35^{\mathrm{bc}}$ & $33.25^{\mathrm{d}}$ & $38.00^{\mathrm{c}}$ & $39.90^{\mathrm{bc}}$ & $7.98^{\mathrm{bc}}$ \\
\hline $\mathrm{T}_{2}$ & $2.10^{\text {cd }}$ & $174.75^{\text {cd }}$ & $26.97^{\mathrm{e}}$ & $32.55^{\mathrm{d}}$ & $38.44^{\text {cd }}$ & $7.69^{\text {cd }}$ \\
\hline $\mathrm{T}_{3}$ & $1.99^{\mathrm{e}}$ & $174.97^{\text {cd }}$ & $32.32^{\mathrm{d}}$ & $29.55^{\mathrm{e}}$ & $38.49^{\text {cd }}$ & $7.70^{\text {cd }}$ \\
\hline $\mathrm{T}_{4}$ & $2.35^{\mathrm{a}}$ & $193.91^{\mathrm{a}}$ & $42.00^{\mathrm{c}}$ & $40.13^{\mathrm{b}}$ & $42.66^{\mathrm{a}}$ & $8.53^{\mathrm{a}}$ \\
\hline $\mathrm{T}_{5}$ & $2.23^{\mathrm{b}}$ & $195.99^{\mathrm{a}}$ & $46.06^{\mathrm{b}}$ & $45.12^{\mathrm{a}}$ & $43.12^{\mathrm{a}}$ & $8.62^{\mathrm{a}}$ \\
\hline $\mathrm{T}_{6}$ & $2.17^{\mathrm{bc}}$ & $186.81^{\mathrm{b}}$ & $50.23^{\mathrm{a}}$ & $38.36^{\mathrm{c}}$ & $41.10^{\mathrm{b}}$ & $8.22^{\mathrm{b}}$ \\
\hline $\mathrm{T}_{7}$ & $2.07^{\mathrm{d}}$ & $174.13^{\mathrm{d}}$ & $28.10^{\mathrm{e}}$ & $29.04^{\mathrm{e}}$ & $38.31^{\mathrm{d}}$ & $7.66^{\mathrm{d}}$ \\
\hline $\mathrm{CD}(0.05)$ & 0.078 & 6.678 & 0.697 & 1.641 & 1.47 & 0.29 \\
\hline $\mathrm{SEm}( \pm)$ & 0.025 & 2.167 & 2.149 & 0.533 & 0.47 & 0.09 \\
\hline
\end{tabular}


Table. 3 Correlation matrix for green fodder yield of fodder maize with soil $\mathrm{C}$ fractions at different depths

\begin{tabular}{|c|c|c|c|c|c|}
\hline \multicolumn{5}{|c|}{ a) } & $0-20 \mathrm{~cm}$ depth \\
\hline & TOC & DOC & LC & RC & GFY \\
\hline TOC & 1 & & & & \\
\hline DOC & 0.266 & 1 & & & \\
\hline LC & $0.623^{* *}$ & -0.243 & 1 & & \\
\hline RC & $0.448^{*}$ & $-0.571^{* *}$ & $0.922^{* * *}$ & 1 & 1 \\
\hline GFY & $0.763^{* * *}$ & 0.332 & $0.811^{* * *}$ & $0.572^{* *}$ & 1 \\
\hline
\end{tabular}

\begin{tabular}{|c|c|c|c|c|c|}
\hline \multicolumn{5}{|c|}{ a) } & $20-60 \mathrm{~cm}$ depth \\
\hline TOC & TOC & DOC & LC & RC & GFY \\
\hline DOC & 0.347 & & & & \\
\hline LC & $0.58^{* *}$ & $0.446^{*}$ & 1 & & \\
\hline RC & $0.455^{*}$ & 0.203 & $0.945^{* * *}$ & 1 & \\
\hline GFY & $0.786^{* * *}$ & $0.654^{* *}$ & $0.727^{* * *}$ & $0.585^{* *}$ & 1 \\
\hline
\end{tabular}

\#\#*** Correlation is significant at 0.001 level (two tailed)

\#\#* Correlation is significant at 0.01 level (two tailed)

\#\# * Correlation is significant at 0.05 level (two tailed)

\section{Correlation analysis between green fodder yield and soil $\mathbf{C}$ fractions}

A significant and positive correlation was obtained between green fodder yield (GFY) and soil LC and RC at both levels of sampling depths which indicates the importance of labile and recalcitrant $\mathrm{C}$ among other $\mathrm{C}$ fractions and can be used as soil indicators to assess the short term effects of nutrient management.

The labile and recalcitrant carbon fractions were strongly and positively correlated to fodder yield in maize. The use of an appropriate combination of fortified organic fertilizers or chemical fertilizers in combination with AMF depending on soil fertility status is a step forward for providing balanced nutrition to crops and increasing profit for farmers. The AMF must be explored at all levels to further investigate their role in nature as a bio-fertilizer for sustainable agricultural production.

\section{Acknowledgement}

Authors thanks to Kerala Agriculture University (KAU) Authorities.

\section{References}

Begum, N., Qin, C., Abass, M., Raza, S., Khan, M. I., Ashraf, M., Ahmed, N. and Zhang. L. 2019. Role of Arbuscular Mycorrhizal Fungi in Plant Growth Regulation: Implications in Abiotic Stress Tolerance. Frontiers in Plant Science. 10:1062.

Blair, G. J., Lefroy, R. D. B. and Lisle, L. 1995. Soil carbon fractions based on their degree of oxidation, and the development of a carbon management index for agricultural systems. Australian Journal of Agricultural Research. 46 (7): 1459-1466.

Bowles, T. M., Barrios-Masias, F. H., Carlisle, E. A., Cavagnaro, T. R. and Jackson. L. E. 2016. Effects of Arbuscular mycorrhizae on tomato yield, nutrient uptake, water relations, and soil carbon dynamics under deficit irrigation in field conditions. 
Science Total Environment. 566: 12231234.

Chan, K. Y., Bowman, A. and Oates. A. 2011. Oxidizible organic carbon fractions and soil quality changes in an oxic paleustalf under different pasture leys. Soil Science. 166 (1): 61-67.

Chen, S., Zhao, H., Zou, C., Li, Y., Chen, Z. and Wang, Z. 2017. Combined Inoculation with multiple arbuscular mycorrhizal fungi improves growth, nutrient uptake and photosynthesis in cucumber seedlings. Frontiers in Microbiology. 8: 25-16.

Else, K. G. B., Chidinma, U. B., Meier, O. J., Gort, G., Comans, R., Mäder, P. and Goede. R. 2019. Sensitivity of labile carbon fractions to tillage and organic matter management and their potential as comprehensive soil quality indicators across pedoclimatic conditions in Europe. Ecological Indicators, 99: 38-50.

FAI (Fertilizer Association of India). 2017. The Fertilizer (Control) Order, 1985. The Fertilizer Associoation of India, New Delhi. Available: http://www.astaspice.org/foodsafety/astas-analytical-methods-manual

Gopinath. P. P. 2021. GrapesAgri1: Collection of Shiny Apps for Data Analysis in Agriculture. Journal of Open Source Software, 6(63): 3437.

Jones, D. L. and Willett. V. B. 2006. Experimental evaluation of methods to quantify dissolved organic nitrogen (DON) and dissolved organic carbon (DOC) in soil. Soil Biology and Biochemistry. 38: 991-999.

Kaste, J. M., Heimsath, A. M. and Bostick. B. C. 2007. Short-term soil mixing quantified with fallout radionuclides. Geology. 35: 20-27.

KAU (Kerala Agricultural University), 2016. Package of Practices Recommendations : Crops (15 ${ }^{\text {th }}$ Ed.), KAU, Thrissur, 360p.

Lal. 2004. Soil C sequestration to mitigate climate change. Geoderma.123: 1-22.

Mitra, D., Navendra, U., Panneerselvam, U., Ansuman, S., Ganeshamurthy, A. N. and
Divya. J. 2019. Role of mycorrhiza and its associated bacteria on plant growth promotion and nutrient management in sustainable agriculture. International Journal of Life Sciences and Applied Sciences. 1: 1-11.

Paterson, E., Sim, A., Davidson, J. and Daniell, T. J. 2016. Arbuscular mycorrhizal hyphae promote priming of native soil organic matter mineralization. Plant and Soil. 408: 243-254.

Rouphael, Y., Franken, P., Schneider, C., Schwarz, D., Giovannetti. and Agnolucci, M M. 2015. Arbuscular mycorrhizal fungi act as bio-stimulants in horticultural crops. Scientia Horticulturae, 196: 91108.

Sanderman, J., Baldock, J. A. and Dangal. S. R. S. 2021. Soil organic carbon fractions in the Great Plains of the United States: an application of mid-infrared spectroscopy. Biogeochemistry. 156: 97-114.

Stevenson. F. J. 1994. Humus Chemistry: Genesis, Composition, Reactions, 2nd ed.; John Wiley \& Sons: New York, NY, USA, 496p.

Sudharmaidevi, C. R., Thampatti, K. C. M., Saifudeen. N. 2017. Rapid production of organic fertilizer from degradable waste by thermo chemical processing. International. Journal of Recycling of Organic Waste in Agriculture. 6: 1-11.

Sun, Z., Song, J., Xin, X., Xie, X. and Zhao. B. 2018. Arbuscular mycorrhizal fungal proteins 14-3-3- are involved in arbuscule formation and responses to abiotic stresses during AM symbiosis. Frontiers in Microbiology. 5: 9-19.

Thirkell, T. J., Charters, M. D., Elliott, A., Sait, S. M. and Field. K. J. 2017. Are mycorrhizal fungi our sustainable saviours considerations for achieving food security. Journal of Ecology. 105: 921929.

Voltr, V., Menšík L., Hlisnikovsky, L., Hruska, M. E., and Pokorny, L. 2021. The Soil Organic Matter in Connection with Soil Properties and Soil Inputs. Agronomy, 22: 32-41. 


\section{How to cite this article:}

Geethu Jacob, K. C. Manorama Thampatti and Naveen Leno. 2021. Soil Carbon Fractions, Growth and Yield as Affected by Different Nutrient Management in Fodder Maize (Zea mays L.). Int.J.Curr.Microbiol.App.Sci. 10(12): 7-13. doi: https://doi.org/10.20546/ijcmas.2021.1012.002 